\title{
Byelorussia still alarmed by the effects of Chernobyl fallout
}

\section{London}

GLASNOST promises to bring some relief to the many in Byelorussia who are alarmed about their continued exposure to fallout from the Chernobyl accident. After months during which public demands for more information have been dismissed by officials as "radiophobia", Byelorussians have now been promised a chance to put their questions and anxieties to panels of

Mogilev and Gomel provinces are to be evacuated because of the persistence of caesium-137 there.

The day after this announcement, a first public meeting on Chernobyl was held at the House of the Trade Unions at Minsk, the capital of Byelorussia. The highlight of the meeting was the production of detailed maps of the contaminated areas which, together with a transcript of the

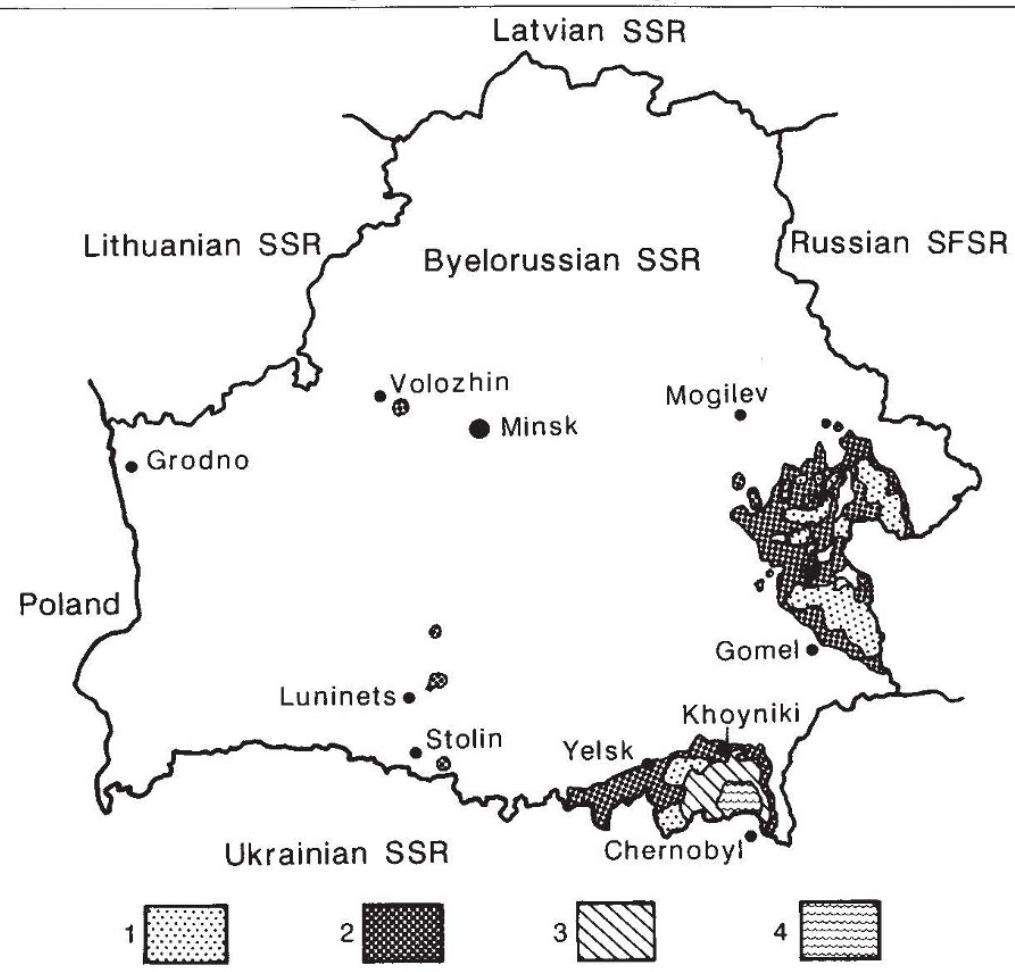

Radiation in Byelorussia, January 1989. (1) Permanently monitored zone. Monthly health-checks on the 103,000 inhabitants. (2) Regularly monitored zone - 206,000 inhabitants. (3) Evacuated zone. 18, 700 inhabitants moved out during June-August 1986. (Now the Polessian State Ecological Reserve.) (4) The original "exclusion zone". Formerly 4,400 inhabitants. (Now the Polessian State Ecological Reserve.)

experts and scientists.

Although Chernobyl is in the Ukrainian republic, the prevailing winds meant that Byelorussia, to the north, caught much of the fallout from the Chernobyl accident nearly three years ago. For several months, there have been indications that the radiation situation in the republic is more serious than had at first been allowed.

Last Octcber, for example, the Prime Minister of Byelorussia, Michal Kovaleu, told the Supreme Soviet of the Soviet Union that "the effect of the Chernobyl disaster in the republic does not decrease". More recently, he told a Pravda reporter that a fifth of the agricultural land in Byelorussia is contaminated.

On 24 January this year, the Supreme Soviet voted an extra 243 million rubles for expenditure in the republic related to Chernobyl, while on 1 February it was announced that a further 20 villages in the proceedings, have since been reproduced in the two leading dailies of the republic.

Among other things, the maps show that 103,000 people live in areas where monthly health checks are required, and that there are 206,000 people in a zone where "regular" checks have been ordered. In the more seriously contaminated zones, no vegetables or fruit may be grown, but local people receive a 25 per cent salary bonus in compensation for the cost of buying food from elsewhere.

There is some confusion about the radiation exposure allowed. A lifetime of exposure of $35 \mathrm{rem}$ has been adopted as a general limit for the population, and evacuation plans are determined by estimates of whether this limit will be exceeded. At the public meeting in Minsk, a deputy minister of health, V. M. Bur'iak, said the authorities are working with limits of $10 \mathrm{rem}$ in the first year of exposure, $3.0 \mathrm{rem}$ in the second and 2.5 rem in the third.

Bur'iak also said that the dose received by the population in the monitored zone of Byelorussia over the whole of the period since the accident amounted to 9.0 rem, compared with 3.3 rem for the rest of Byelorussia. But he also acknowledged that 48 pensioners who had ignored official advice and returned to the homes from which they had been evacuated had. received doses exceeding the limits, while insisting that "none of those who were evacuated received the limit dose of 75 rem".

Although the opening statements by officials at the meeting suggested that the radiation situation in Byelorussia is well in hand, questions from the floor occasionally produced evidence of muddles and mistakes. Thus it was acknowledged that the civil defence manuals had not foreseen the need to evacuate rural areas, while there have been delays in providing the promised tractors with sealed cabs for working contaminated land more safely. Some participants at the meeting, dissatisfied with assurances that food reaching the shops is safe, demanded radiation monitors so as to be able to check for themselves.

Many speakers at the meeting were sharply critical of the official approach to the clean-up operations, suggesting for example that it would be more economical to let contaminated land lie fallow than to attempt to produce "safe" grain and meat from it. Complaints that illnesses have been more common in the region since the accident were met, at the meeting in Minsk, with the reply that there was an influenza epidemic and that medical monitoring brings more minor illnesses to light. But why, one questioner asked, have so many medical personnel, who must know the real risks, quit the region? Plainly, many more public meetings will be needed before the population is content.

Vera Rich

\section{More West German university investment?}

\section{Bonn}

THE federal government is prepared to spend more on universities if it is joined by the Länder, the West German Education Minister Jürgen Möllemann announced on 10 February. Möllemann suggested an increase of DM600 million a year in the federal budget for university construction, with half of that amount coming from the Länder. The budget now stands at DM2,000 million.

The DM2,000 million "emergency programme" announced in December to relieve chronically overcrowded university courses (see Nature 336, 704; 1988) will take effect as soon as it is approved by the heads of the Länder. Steven Dickman 